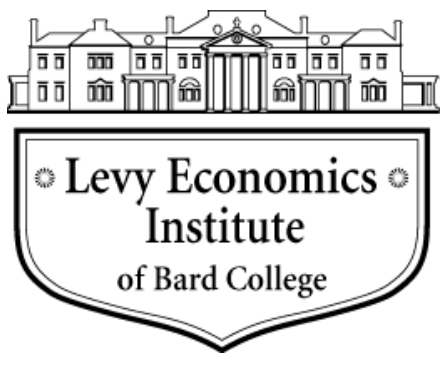

Working Paper No. 950

\title{
Public Charge in the Time of Coronavirus
}

by

\author{
Martha Tepepa \\ Levy Economics Institute \\ of Bard College
}

\section{April 2020}

The Levy Economics Institute Working Paper Collection presents research in progress by Levy Institute scholars and conference participants. The purpose of the series is to disseminate ideas to and elicit comments from academics and professionals.

Levy Economics Institute of Bard College, founded in 1986, is a nonprofit, nonpartisan, independently funded research organization devoted to public service. Through scholarship and economic research it generates viable, effective public policy responses to important economic problems that profoundly affect the quality of life in the United States and abroad.

Levy Economics Institute

P.O. Box 5000

Annandale-on-Hudson, NY 12504-5000

http://www.levyinstitute.org

Copyright (C Levy Economics Institute 2020 All rights reserved

ISSN 1547-366X 


\begin{abstract}
The United States government recently passed legislation and stabilization packages to respond to the COVID-19 (i.e., coronavirus disease 2019) outbreak by providing paid sick leave, tax credits, and free virus testing; expanding food assistance and unemployment benefits; and increasing Medicaid funding. However, the response to the global pandemic might be hindered by the lassitude of the state and the administration's conception of social policy that leaves the most vulnerable unprotected. The administration's "zero tolerance" immigration campaign poses public health challenges, especially in the prevention of communicable diseases. In addition to the systemic obstacles noncitizens face in their access to healthcare, recent changes to immigration law that penalize recipients of some social services on grounds that they are a public charge will further restrict their access to treatment and hinder the fight against the pandemic.
\end{abstract}

KEYWORDS: Public Charge; Public Services; Coronavirus; COVID-19; Social Policy; State; Means Testing; Public Assistance; Welfare Policy; Free Rider

JEL CLASSIFICATIONS: H4; H550; H570; H750; H840; I380; O15; O510; Z180 
The United States government recently passed legislation and stabilization packages to respond to the COVID-19 (i.e., coronavirus disease 2019) outbreak by providing paid sick leave, tax credits, and free COVID-19 testing; expanding food assistance and unemployment benefits; and increasing Medicaid funding. 'Under the Senate Republicans' original bill, individuals could receive one-time checks of a maximum of $\$ 1,200$ or $\$ 2,400$ for married couples, plus $\$ 500$ per child. Those earning more money would get a bigger check and the payment would phase out for those earning more than $\$ 75,000$, ending entirely for taxpayers with more than $\$ 99,000$ in income or families earning $\$ 198,000$," with the initial measure also stating that "it will reduce payments to $\$ 600$ for people with no income tax liability but at least $\$ 2,500$ in earnings" (Hulse 2020). Thus, people with lower income levels would receive less cash. Lawmakers from both parties attacked this and eventually it was decided that the full amount would be sent to those families as well.

The Coronavirus Aid, Relief, and Economic Security (CARES) Act passed by unanimous vote in the Senate and was signed into law on Friday, March 31, 2020 (the health crisis started in late February, evidence of the lack of direction and unpreparedness of the governing elite). The CARES Act includes a delay for the payment of the employer payroll tax —one of the primary funding mechanisms for Social Security—for the rest of 2020. Corporations like airlines, cruise companies, and fossil fuel firms would receive a $\$ 500$ billion business relief program "slush fund" controlled by the administration. The population that is already registered with the Internal Revenue Service (IRS) or the Social Security Administration will receive automatic payments, while those that don't normally file a return with the IRS and/or lack a standard checking account will face more challenges in receiving their check. ${ }^{1}$

The implicit intent of the government's first direct action is to continue ceding all crucial initiatives to the private sector, reinforcing the market's dominance, while undercutting the state's strategic intervention, a process evident during the first year of the administration, when the reconstruction of Puerto Rico's economy after Hurricane Maria was left to the private sector

\footnotetext{
${ }^{1}$ Graetz and Shapiro (2020) have shown that families receiving government aid are usually unbanked. Their use of prepaid debit cards, check-cashing facilities, and payday loan operations is common since they don't maintain a bank account. An additional hurdle is that many states make qualifying for and receiving benefits difficult.
} 
(Weisbrot 2019). The administration's initial unwillingness to use the Defense Procurement Act to speed up the production of medical equipment necessary to combat the pandemic also demonstrates their aversion to direct market intervention. The retraction of the state's involvement during the pandemic allows the potential for colossal profits for specific industries like biotechnology firms, major pharmaceuticals firms, makers of generic drugs, medical equipment manufacturing firms, and health insurance companies.

So far, the question of the virus' impact has been addressed, but one important fact that has not been addressed is access to treatment for all. Some families might not get their thousand dollars in the mail, but even if they get their check, it will make little difference because most likely they will not have access to treatment if they get sick.

Throughout history there have been pandemics that wipe out human assumptions of invincibility and reveal the mighty power of tiny pathogens to bring us down without discrimination: poor, rich, white, black, old, young, male, female, and so on. In Love in the Time of Cholera, Nobel Prize-winner Gabriel García Márquez (1988) writes a love story set in a coastal town near the Magdalena River, weaving in details of the epidemic of cholera morbus that ravaged Colombia. The profound inequalities of the region in the nineteenth century, when the story is set, are reflected in the extreme social-spatial division: the great families of European descent (local aristocrats) and the popular class inhabit the inner city. The colonial infrastructure is crumbling, Spanish-built sewers discharge waste into the cove, and the market operates on top of its own garbage heap where offal from the slaughterhouse is also thrown away. While old colonial mansions have latrines and septic tanks, the black population and outcasts who represent twothirds of the population are relegated to shantytowns on the outskirts where, lacking any infrastructure, they relieve themselves in the open air. Eventually, their excrement turned into dust, filling the lungs of all. Not only was breathing lethal, drinking water was also harmful since it was a sanctuary for water worms and lacked the chemical composition that makes it safe for human consumption. ${ }^{2}$

\footnotetext{
${ }^{2}$ This description is sadly valid today for many irregular settlements through Latin America and Asia. As of 2020, many communities have inadequate access to safe and potable water; inadequate access to healthcare infrastructure, precarious and low-quality housing, high levels of overcrowding, and undetermined legal property and residential status (UN 2003).
} 
In the novel, as in real life, the cholera epidemic does not discriminate in who it infects, but hits the poor much harder than the wealthy, mainly because of their lack of access to sanitary conditions. It is calculated that during the cholera epidemic that blasted Colombian towns along the Caribbean coast in the mid- to late-nineteenth century the mortality rate was 50 percent and over 200,000 people died.

García Márquez said that the novel was his most political and critical of the traditional local power groups (Simons 1988). The governing elite seems lethargic, almost immobile, too invested in promoting their noble descent and in their internal fights for power. They are disconnected from the realities of the putrefaction of the city, the overt exploitation of natural resources, and the general deterioration of the environment. The epidemic finds them underprepared and unable to manage a city under siege from a deadly contagion.

\section{EPIDEMICS AND THE STATE}

The state is an essential part of the design and implementation of policies that guide the nation's development:

The State assumes a strategic and leading role through a combination of democratic planning within all sectors: the market, the public, the private. [The national development strategy] expresses the will of a hegemonic group and a coalition of forces, with interests, objectives, resources and powers, but capable of coincidences. Through the State, a hegemonic group or coalition, in the conditions and under the determinations of a given society and of a certain phase of its evolution, can mobilize and use a diversity of resources, through its decisions and activities, for the achievement of its conservation or change objectives, in coincidence with a confrontation with other groups of different interests and projects. Development strategies and policies are specified through questions and dilemmas, answers and solutions, establishing balances and combinations (Kaplan 1995, 45-46).

The state provides and satisfies basic needs - mainly those related to economic well-being, education, and healthcare - through social policy. The state's actions are the result of the government's conception of social problems and the characteristics of the instruments adopted to 
tackle them. In some countries, the state is the main guarantor and regulator; in others the action is delegated to the private sector and its organizations.

According to Keynes's concept of the Social State, the combination and conjunction of economic growth on the one hand and a better redistribution of wealth on the other-economic development plus social welfare-leads to greater social justice (Wray 2005, 2). Under this approach, one of the state's main functions is the improvement of the population's general wellbeing. Thus, extreme poverty in a country is the most acute expression of the fact that the economic and social structure of the state and the ruling government have not satisfied the needs of all (Filgueira 2005, 2).

The conceptualization of the state's action presents different ethical, ideological, and political orientations. Its design mixes a series of actors with different principles and interests, which influence the final result and the type of tools applied: "Ideally, the objective of all social development policies is to put an end to economic inequalities and imbalances, assuming the role of redistributing income in favor of the weakest" (Sen 2003).

The social policy model of the United States can be described as a means-tested assistance model according to the typology proposed by Esping-Andersen. ${ }^{3}$ In this model, the social safety net forces participants to integrate into the market through policies based on means tests that offer a minimum coverage with meager benefits. This model strengthens the market's role because everyone is forced to contract private assistance while the state is a mere facilitator that delegates responsibility, production, action, and profits to the private sector. The benefits are scarce and generally associated with social stigma (similar to the nineteenth-century Poor Laws in the United Kingdom) provoking embarrassment, resentment, or shame. By stigmatizing and punishing participants, the model promotes a dual social system.

For example, families interested in receiving the housing choice voucher program must prove that their family income and assets are below a certain level set by the US Department of

\footnotetext{
${ }^{3}$ Also called residual or liberal.
} 
Housing and Urban Development (HUD), the program's administrator. ${ }^{4}$ The information provided by applicant families is verified by local agencies, employers, and banks; if approved, the amount of housing assistance is calculated based on the rent for a moderately priced dwelling unit in the local market. The family can select a unit with a rent that is below or above the payment standard and "must pay 30 percent of its monthly adjusted gross income for rent and utilities, and if the unit rent is greater than the payment standard the family is required to pay the additional amount" (HUD 2020). Despite the huge demand for housing assistance, the resources available to HUD and the local housing agencies have been cut in the administration's fiscal year 2020 budget request. This action will eliminate or deeply cut essential housing and community development programs like the national Housing Trust Fund, the HOME Investments Partnership program, and public housing capital repairs, leaving families in need on waiting lists and facing homelessness: "Overall, the administration proposes to cut HUD by an astounding $\$ 9.6$ billion or 18 percent below 2019 enacted levels, imposing deep cuts to affordable housing and community development, as well as other essential programs that ensure basic living standards" (NLIHC 2020).

Gordon (2004) argues that the orthodox policies in the means-tested assistance model rest on three elements: economic growth, human capital development through education, and a minimum social safety net for the poor. He stresses that the axis on which these types of policies rest - privatization, liberalization of the capital market, and a system of prices controlled by the market and free trade - has, in many countries, led to, among other things, increases in poverty levels: "Countries can open their economies and not generate growth or human development. Russia generated trade and attracted private capital flows with the opening in the 1990s, but economic stagnation and human deprivation are severe. Between 1989 and 1996, men's life expectancy fell by almost four years to 60 , two years less than the average for developing countries. The under-five mortality rate is 25 per 1,000 live births, compared to 14 in Poland. In addition, homicides and illegal drug trafficking have increased" (UNDP 1999, 85).

\footnotetext{
${ }^{4}$ The housing choice voucher program "is the federal government's major program for assisting very low-income families, the elderly, and the disabled to afford decent, safe, and sanitary housing in the private market. Since housing assistance is provided on behalf of the family or individual, participants are able to find their own housing, including single-family homes, townhouses and apartments" HUD (2020).
} 
Aside from the limited reach of social policies, the US government's current position on the origin of social problems, as well as on the perception of policy recipients, is to assume that they are product of individual failures — people lacking skills and entrepreneurship — and judging those that fall behind (the poor) as lazy, delinquent, and unworthy of assistance: "the dominant culture [in the United States] spreads the idea that the poor are in that situation because they have certain behaviors resulting from moral deficiencies or a wrong system of values" (Schteingart 1999, 340). Among those not blamed for their situation are women, widows, the disabled, children, and the elderly, often called "vulnerable" population. Ideal citizens are individuals believed to have more potential to make economic contributions and live within their own means without relying on social programs, though those who demonstrate higher employability, consistently demonstrate agency-verified need, or suffer from severe vulnerabilities can be considered deserving.

These perceptions, however biased they might be, are the social realities guiding the US government in addressing needs. Ideally, the state's interventions are fact-based and antidiscriminatory. However, under the current administration, this is not possible since there are clear prejudices harbored by frontline public sector workers and policymakers that translate into overt discriminatory treatment of citizens in need, while noncitizens are subjected to a "public charge" consideration.

\section{PUBLIC CHARGE}

The word "charge" has many meanings in the Webster's Third New International Dictionary of the English Language, but the one that can be applied unambiguously to a person and best clarifies the phrase "become a public charge" is "a person entrusted to the care, custody, management, or support of the public system." The term has been defined by the United States Department of Justice Immigration and Naturalization Service (INS) as "a complete, or nearly complete, dependence on the Government for subsistence, as demonstrated by either the receipt of public cash assistance for income maintenance or institutionalization for long-term care at Government expense" (INS 1999). 
During the early years of the United States, individuals who became dependent on the government were institutionalized in asylums or placed in almshouses for the poor. As the welfare state developed, a model of limited-purpose public assistance was established against the backdrop of the "public charge" concept used in immigration law beginning in the late 1800s.

The term public charge reflects the concept of dependency, rather than solidarity, and has been in use for more than a century. A recent use dates from the 1996 Personal Responsibility and Work Opportunity Reconciliation Act (PRWORA) program of welfare reform signed by President Clinton, which imposed new restrictions on noncitizens' eligibility for federal, state, and local public benefits. The eligibility restrictions did not include receipt of emergency medical assistance; short-term, in-kind, emergency disaster relief; public health assistance related to immunizations and treatment of a communicable disease; certain in-kind services (e.g., soup kitchens, etc.) designated by the attorney general as necessary for the protection of life and safety; and assistance under certain HUD programs.

Though legally eligible, accepting benefits such as cash assistance for income maintenance benefits, including Supplemental Security Income (SSI) and Temporary Assistance for Needy Families (TANF), as well as other state or local cash assistance programs may result in an individual being determined a public charge and affect a noncitizen's right to remain in the United States (a person is also considered a public charge if they are institutionalized at the government's expense other than imprisonment for conviction of a crime). The rule states that in terms of immigration status, the "aliens" that receive any form of cash assistance for income maintenance or are institutionalized for long-term care are not necessarily inadmissible, ineligible to adjust status, or deportable on the grounds that they are a public charge: “... the law requires that a variety of other factors and prerequisites must be considered as well" (INS 1999).

The restrictions led numerous noncitizens to refrain from applying for benefits, fearing the negative consequences of potentially being deemed a public charge. ${ }^{5}$ This presents negative

\footnotetext{
${ }^{5}$ Although the Public Charge rule assures that noncitizens won't be automatically deemed public charge, it leaves open the possibility that receiving aid might impact their status later: "The rule will provide rules of decision that will apply in proceedings before the Executive Office for Immigration Review (EOIR), as well as proceedings
} 
public health consequences, especially for the treatment of communicable diseases. If a large segment of the population fears obtaining necessary medical treatment, it will not only cause considerable harm to families, but will jeopardize the general public. For example, infectious diseases may spread as a large percentage of the population declines immunization or if they refuse to seek — or are refused — treatment during a pandemic. This tension between immigration and welfare laws is exacerbated by the recent changes to immigration laws pushed by the Trump administration.

On February 24, 2020, the Inadmissibility on Public Charge Grounds final rule was implemented nationwide. Citing the basic principle of self-sufficiency in the United States since the earliest immigration waves of the $1800 \mathrm{~s}$, the government put into statute that those unable to care for themselves without becoming a public charge are inadmissible in the United States. The final rule requires that noncitizens seeking to preserve, extend, or change their immigration status show that they have not received public benefits (as defined in the rule) over a designated threshold.

\section{CORONAVIRUS}

The novel coronavirus (COVID-19), first labeled as SARS-CoV2, emerged in Wuhan, China at the end of 2019. The virus quickly spread to all Chinese provinces and the World Health Organization declared the spread of COVID-19 a pandemic on March 11, 2020. As of April 4, 2020, authorities in 206 countries and territories had reported more than 1,134,000 cases. Although countries have taken several actions to contain the virus, the effectiveness of these efforts is unknown due to the uncertainties regarding the pathogen's transmissibility and its virulence. Li et al. (2020) found that a high proportion of people with undocumented infections, "many of whom were likely not severely symptomatic, appears to have facilitated the rapid spread of the virus throughout China. Indeed, suppression of the infectiousness of these undocumented cases in model simulations reduces the total number of documented cases and the

before the Service. The Department anticipates, based on the Service's consultations, that the State Department will adopt the same view and will issue guidance to consular officers accordingly" (INS 1999). 
overall spread of SARS-CoV2." Their findings underscore the importance of the state's action and efficiency:

\begin{abstract}
Presently, there are four, endemic, coronavirus strains currently circulating in human populations (229E, HKU1, NL63, OC43). If the novel coronavirus follows the pattern of $2009 \mathrm{H} 1 \mathrm{~N} 1$ pandemic influenza, it will also spread globally and become a fifth endemic coronavirus within the human population... [Our] findings also indicate that a radical increase in the identification and isolation of currently undocumented infections would be needed to fully control SARS-CoV2. Increased news coverage and awareness of the virus in the general population have already likely prompted increased rates of seeking medical care for respiratory symptoms. In addition, awareness among healthcare providers, public health officials and the availability of viral identification assays suggest that capacity for identifying previously missed infections has increased. Further, general population and government response efforts have increased the use of face masks, restricted travel, delayed school reopening and isolated suspected persons, all of which could additionally slow the spread of SARS-CoV2. (Li et al. 2020)
\end{abstract}

\title{
PUBLIC CHARGE AND CORONAVIRUS IN TIMES OF RACISM AND XENOPHOBIA
}

During disease outbreaks, attacks on marginalized groups are not an exception, but the norm. Racism and xenophobia are enhanced by discourse that targets certain ethnic groups, suggesting they are at fault for spreading the disease or are free riders who take resources that should not be available to them. Pandemics increase far-right extremism and prejudiced attitudes toward those who look different. Examples of this are found throughout history, with European colonists blamed for America's smallpox epidemic in the sixteenth century, Jewish communities targeted during the bubonic plague, and Irish immigrants blamed for typhoid in the 1800s. Immigrants without papers have also been prosecuted for accessing cash assistance, long-term institutionalized care, or medical attention that many believe should be reserved only for citizens. Nonwhite legal residents are also scrutinized for their use of public services and labeled as undeserving. Refugees are often accused of draining resources and struggle to counter extremist narratives and social distrust in host communities.

Immigration policies in the United States have intensified these sentiments and could undermine efforts to detect and combat the COVID-19. Those apprehended after crossing the border will most likely be put in detention facilities with poor conditions, such as crowded and cramped 
environments, which are detrimental to epidemic management. Immigrants without papers already in the United States might not seek care out of fear of deportation. Parents that might be infected will likely prefer to avoid scrutiny and keep working, increasing the chance of spreading the virus.

The administration's "zero tolerance" approach to immigration poses an obstacle to treatment and will hinder the fight against the pandemic. In the time of COVID-19, these additional attacks leave migrants at a disadvantage when facing segregationist measures such as "English only" policies meant to expel languages other than English from the public sphere. For example, in Arizona, where 30 percent of the residents are Hispanic, the state's department of health services has a portal with updated information about the pandemic, but there is nothing in Spanish. This translates into lack of information for non-English speakers, as a large number of people who do not read in English will not receive information and directions to take precautions to reduce the danger of being infected, and families won't be prepared in case they get sick or if the government orders confinement. Nuzzo (2018) studied a mumps outbreak in an immigrant community in Pennsylvania where many people in the community spoke little or no English, and some did not have health insurance or official immigration documentation. The study found that the outbreak was exacerbated because some cases and their contacts may have been deterred from seeking care since they were afraid to be identified as "undocumented immigrants" and reported to immigration officials.

\section{PUBLIC CHARGE, SOCIAL POLICY, AND COVID-19}

On their website, the United States Citizenship and Immigration Services (USCIS 2020) office encourages "all those, including aliens, with symptoms that resemble Coronavirus Disease 2019 (COVID-19) (fever, cough, shortness of breath) seek necessary medical treatment or preventive services. Such treatment or preventive services will not negatively affect any alien as part of a future Public Charge analysis.” The website also stresses that the Public Charge Grounds final 
rule implemented on February 24, $2020^{6}$ "does not restrict noncitizens' access to testing, screening, or treatment of COVID-19 through public sources and to a vaccine, if ever devised, to combat the virus - critical to defending and protecting Americans' health and its health care resources."

The Public Charge rule also signals that the receipt of public benefits through public treatment or paid by Medicaid, for example, might be considered when weighing the immigration status of noncitizens, thus encouraging noncitizens to use the resources offered by the private sector, and discouraging them to apply for or accept public aid, even if they desperately need it. The rule also mentions the consequences of social distancing or quarantine to prevent the spread of COVID-19. Since noncitizens might be prevented from working or attending school, some might rely on public benefits for the duration of the outbreak and recovery phase; thus, they must provide an explanation and relevant supporting documentation. USCIS will determine if their claim is relevant and credible, and if it will be considered in the totality of the circumstances.

Labeling those that receive social programs and benefits as public charge not only labels people, but "deservedness" shapes service and policy responses toward them. The term public charge involves perceptions that are distinct from the formal assertion of rights or policies and informs the decisions that are made about access to public services. During the time of the COVID-19 pandemic, even when noncitizens are granted legal or policy rights to healthcare, these could be denied by frontline health staff if they are not perceived as deserving of care. The health implications for mobile populations subjected to this kind of discrimination can be profound and during this epidemic can have a serious impact beyond "defending and protecting Americans' health" (USCIS 2020).

\footnotetext{
${ }^{6}$ On their website, USCIS states "the Inadmissibility on Public Charge Grounds final rule will be implemented in the United States on Feb. 24, 2020, except in Illinois, where the rule remains enjoined by a federal court as of Jan. 30,2020 . The final rule will apply only to applications and petitions postmarked (or submitted electronically) on or after Feb. 24, 2020" (USCIS 2020).
} 


\section{CONCLUSIONS}

The actions of the United States government through the pandemic will be less than optimally effective if they don't reach typically overlooked groups, and if they don't acknowledge that public panic and fear-fueled by the government's xenophobia and racist discourse — can be detrimental during a public health emergency. When the state renounces the role of providing basic services for the well-being of its citizens, it leaves the door open for the private sector and other entities to profit from supplying strategic services during crucial times.

Migration is a human phenomenon that brings a discussion of key human values: dignity, compassion, and respect. An elitist, racist, and cruel society is a nation drained of human values where corporations deserve more than humans. When a country instead shows concern for everyone, in taking care of them, it grows. During a similar emergency, the Great Depression, through President Roosevelt's guidance, the state restored public confidence by guaranteeing that the people most affected were able to get back on their feet. While the private sector had a role, the state corrected the imbalance created by ruthless capitalism (Moley 1966). COVID-19 will expose the difference between social solidarity in the face of the epidemic and social violence in the absence of a public health system that has been privatized to enrich those with a financial advantage due to political corruption. 


\section{REFERENCES}

Filgueira, F., C. G. Molina, J. Papadópulos, and F. Tobar 2005. "Universalismo básico: una alternativa posible y necesaria para mejorar las condiciones de vida en América Latina." In C. Molina (ed.), Universalismo básico: Una nueva política social para América Latina. Washington, DC: Banco Interamericano de Desarrollo, Editorial Planeta.

García Márquez, Gabriel. 1988. Love in the Time of Cholera. 1st American ed. Edith Grossman, trans. New York: Alfred A. Knopf.

Gordon, D. 2004. "The International measurement of poverty and anti-poverty policies." In P. Townsend and D. Gordon (eds.), World Poverty: New Policies to Defeat an Old Enemy. 2nd. ed. Bristol: The Policy Press.

Graetz, M., and I. Shapiro. 2020. The Wolf at the Door: The Menace of Economic Insecurity and How to Fight It. Cambridge, MA: Harvard University Press.

HUD (United States Department of Housing and Urban Development) 2020. "Housing Choice Vouchers Fact Sheet." Available at: https://www.hud.gov/topics/housing_choice_voucher_program_section_8

INS (United States Department of Justice Immigration and Naturalization Service). 1999. "Proposed Rule on Inadmissibility and Deportability on Public Charge Grounds; Field Guidance on Deportability and Inadmissibility on Public Charge Grounds; Proposed Rule and Notice.” Federal Register 64(101).

Kaplan, M. 1995. “Teoría y realidad del Estado en América Latina.” In M. Mols and J. Thesings (eds.), El Estado en América Latina. Buenos Aires: Centro Interdisciplinario de Estudios sobre el Desarrollo Latinoamericano, Fundación Konrad Adenauer.

Lee, M. 2020. “Coronavirus fears show how 'model minority' Asian Americans become the 'yellow peril."” NBC News, Self-Explanatory blog. Available at: https://www.nbcnews.com/think/opinion/coronavirus-fears-show-how-model-minorityasian-americans-become-yellow-ncna1 151671 (accessed March 12, 2020).

Li, R., S. Pei, B. Chen, Y. Song, T. Zhang, W. Yang, and J. Shaman. 2020. "Substantial undocumented infection facilitates the rapid dissemination of novel coronavirus (SARSCoV2)." Science Research Article, March 16. Available at: http://science.sciencemag.org/content/early/2020/03/13/science.abb3221.abstract (accessed March 16, 2020).

McFadyen, J. 2020 "Immigrants and Public Benefits." ThoughtCo. Available at: https://www.thoughtco.com/immigrants-and-public-benefits-1951828 (accessed March 9, 2020).

Moley, R. 1966. The First New Deal. New York: Harcourt, Brace \& World, Inc. 
NLIHC (National Low Income Housing Coalition). 2020. "President Trump Proposes Drastic Cuts to Affordable Housing Programs.” Analysis of President Trump's FY2020 Budget Request, March 11. Available at: https://nlihc.org/resource/analysis-president-trumpsfy2020-budget-request

Nuzzo, J. 2019. "Responding to a Mumps Outbreak in a Hard-to-Reach Community." Outbreak Observatory Report. Baltimore: John's Hopkins Bloomberg School of Public Health. Available at: https://www.outbreakobservatory.org/outbreakthursday1/10/10/2019/responding-to-a-mumps-outbreak-in-a-hard-to-reach-community (accessed March 17, 2020).

Schteingart, M. 1999. Políticas Sociales para los Pobres en América Latina. México City: Miguel Ángel Porrúa.

Sen, A. 2003. “La economía política de la focalización.” Comercio Exterior 53(6).

Simons, M. 1988. "García Márquez on Love, Plagues and Politics.” The New York Times, February 21.

UN (United Nations). 2003. "The Challenge of Slums.” United Nations Human Settlements Program 2003 Global Report on Human Settlements. London and Sterling, VA: Earthscan Publications.

UNDP (United Nations Development Program). 1999. "Human Development Report.” New York: Oxford University Press.

USCIS (United States Citizenship and Immigration Services). 2020. "Public Charge Fact Sheet." Available at: https://www.uscis.gov/news/fact-sheets/public-charge-fact-sheet (Last reviewed/updated: February 27, 2020; accessed March 21, 2020).

Weisbrot, M. 2019. “Puerto Rico’s Botched Disaster Relief, Unsustainable Debt, and Economic Failure Linked to its Colonial Status" CEPR article, May 30. Washington, DC: Center for Economic and Policy Research. Available at: https://www.cepr.net/puerto-rico-sbotched-disaster-relief-unsustainable-debt-and-economic-failure-linked-to-its-colonialstatus/

Wray, L. R. 2005. “Social Security’s 70th Anniversary: Surviving 20 Years of Reform.” Policy Note 2005/6. Annandale-on-Hudson, NY: Levy Economics Institute of Bard College. 